\title{
Minority Discount for Reduced Powers in Negotiations of Non-Listed Minority Holdings: Evidence from European Countries
}

\author{
Massimiliano Celli ${ }^{1}$ \\ ${ }^{1}$ Department of Business Studies, University of Roma TRE, Via Silvio D’Amico 77, 00145 Rome, Italy \\ Correspondence: Massimiliano Celli, Department of Business Studies, University of Roma TRE, Via Silvio \\ D’Amico 77, 00145 Rome, Italy. E-mail: massimiliano.celli@uniroma3.it
}

Received: February 1, 2017

Accepted: February 20, 2017

Online Published: March 26, 2017

doi:10.5539/ijbm.v12n4p23

URL: https://doi.org/10.5539/ijbm.v12n4p23

\begin{abstract}
This article aims at giving a contribution to the issue of valuating the minority discount for reduced powers in purchase/sale transactions of non-listed minority interests. Firstly, the meaning of minority discount for reduced powers will be investigated as well as its economic determinants, specifically pointing out that the economic rationale behind this type of minority discount lies in the impossibility for the minority purchaser to gain the prerogatives associated to a controlling position. Then the analysis will focus on the considered examination of the evaluation criteria of minority interests in businesses non-listed on official markets developed by main doctrine, at the same time singling out the salient and peculiar features thereof together with some comments and in-depth studies on the subject-matter. In this respect the main features of both direct and indirect valuation criteria will be analysed, specifically focusing on the second ones which measure the economic value of such minority interests by executing a discount percentage to the pro-rata value of the whole company's economic capital (W). Finally the methods most often utilised by the European well-qualified professional praxis to measure the value of minority interests non-listed on regulated markets will be investigated. To this purpose, a number of official reports concerning purchase/sale transactions of minority interests in European non-listed companies will be examined. Finally, some conclusions on the topic at stake will be drawn.
\end{abstract}

Keywords: minority interests, minority discounts, lack of control, non-listed companies

\section{Introduction and Study Objectives}

In sale and purchase transactions of minority interests in companies which are not listed on regulated markets, the sale price actually agreed between the parties rarely coincides to the corresponding pro-rata value of the company's overall economic capital (W), due to the influence on the decisions of each party of the so called "subjective conditions of negotiation", as well as to the "prerogatives" correlated to the interest in the corporate capital that is being traded.

Among the subjective conditions which may affect the evaluation process of a minority interest (and, therefore, the purchase price) the following may be identified:

- Different business-related motivations for each party (such as, for instance, the interest to enter into a new market/sector, or of reaching new synergies and/or cost efficiencies as a consequence of the acquisition of a given company, etc.);

- Private non-rigorously business-related elements, such as the trading ability of each counterpart and its resulting negotiating power, and others (predilection for personal prestige, social reputation etc.);

- $\quad$ Possible information asymmetries.

With specific regard to the prerogatives associated with the interest in the corporate capital that is being negotiated, when it provides the purchaser relevant control rights upon the company, or is useless for this purpose, a discrepancy can be discovered within the financial value of the exchanged interest and the correlative pro-rated value of the economic capital (i.e. base or found value). This divergence aims to provide a fair assessment to the further control requirement, when it occurs or when it is absent.

If the interest traded allows the purchaser to achieve a predominant position over the company (or to condition its directors considerably), its financial value is esteemed by computing a given monetary worth to the 
correspondent pro-rated value of the whole company's economic capital, called "majority premium" or also "control premium". When the interest exchanged does not let the purchaser to achieve a substantial influence over company's operations, its market value is assessed by reducing of a given percentage the corresponding base-value. Such percentage reduction is called "minority discount for reduced powers" or also "minority discount for lack of control".

This research aims to give a contribution to the issue of valuating the minority discount for reduced powers in purchase/sale transactions of minority interests non-listed on official markets. To this purpose, after having analysed the economic rationale of minority discount due to lack of control as well as its factual determinants, the study will focus on the considered examination of the evaluation criteria of minority interests in companies not listed on official markets, as developed by main international scholars, at the same time singling out the main peculiar features thereof together with some comments and in-depth studies on the subject-matter. Then it will investigate which evaluation criteria are most often used by the European well-qualified professional practice.

Instead, it is outside the scope of this article the evaluation of discounts for lack of marketability in sale/purchase transactions of minority interests (also said "liquidity discounts"), which, in theory, should be calculated when the traded interests cannot be easily sold to third parties within a reasonable period of time and for a fair value, due to their absolute irrelevance from qualitative and quantity stand-point. Furthermore, according to the prevailing international scholars and professional practice such additional discount should apply only to irrelevant minority interests listed on official markets (and, anyway, only upon occurrence of specific conditions), whereas, with respect to holdings in not listed companies it is usually "absorbed" by the discount due to reduced powers. In any case, it is a matter of fact that any holding in not listed companies should be generally considered "not liquid", irrespective from its dimension (with obvious exceptions to be considered on a case-by-case basis).

The article is organized as follows. The following paragraph gives a literature overview of the topic at stake. In paragraph 3, we investigate the significance of minority discount for reduced powers and explore its economic determinants. Specifically, we point out that the economic rationale behind this type of minority discount lies in the impossibility for the minority purchaser to gain the prerogatives associated to a predominant position (normally called "private benefits of control"). In paragraph 4, we examine the methods utilised to measure the market value of minority interests in the corporate capital of companies unquoted on regulated markets (and so the minority discounts for reduced powers) elaborated by the main international doctrine. We examine the principal features of both direct and indirect valuation criteria specifically focusing on the second ones, which measure the financial value of minority interests by executing a discount percentage to the corresponding economic base value. In paragraph 5, we investigate which of the estimation criteria examined in this article are most often utilised by the European well-qualified professional praxis. To this purpose, we examine No. 250 reports drawn up by financial experts (specifically consulting firms, law firms and financial institutions) concerning purchase/sale transactions of minority interests in E.U. medium and large companies non-listed on official markets throughout the period 2000-2015. In paragraph 6, we draw some conclusions on the topic at stake.

\section{Literature Overview}

The issue of minority discount valuation due to lack of control in the transaction of holdings unquoted on regulated markets has been the subject of a very limited number of theoretical and empirical contributions over the years. However there are numerous references on more or less related matters.

International doctrine has in fact converged on the theoretical development of appropriate methodologies to calculate majority/control premiums (Covrig, McConaughy, \& Travers, 2015; Suzuki, 2015; Cornell, 2013) by which is meant the highest financial value - with regard to the bottom base value - of interests that, because of their relevance with respect to the whole capital share, attribute to the purchaser the full dominion over the branch company. Many researchers and practitioners have therefore focused on the valuation of majority/control premiums, with specific regard to the transaction of interests listed on regulated markets (Covrig, McConaughy \& Travers, 2016; Hauser \& Lauterbach, 2004), from which most of the methodologies currently used by professional practice to estimate control/majority premiums of non-listed companies are derived (Bogatyrev \& Dobrynin, 2015; Chari, Ouimet, \& Tesar, 2010).

Even larger are the studies of researchers and practitioners relating the analysis of the economic rationale behind control/majority premiums, by which is meant the possibility for the purchaser of the majority interest of a company to draw from the company itself the commonly-named monetary and non-monetary "attributes of control" (Damodaran, 2012; Gopalan \& Jayaraman, 2011; Doidge, Karolyi, Lins, Miller \& Stultz, 2009; Nenova, 2003; Bae, Kang \& Kim, 2002; Barclay \& Holderness, 1989). 
Several researchers (Pratt, 2015; Yee, 2005) as well as the best practice in this field (specifically merchant banks, law firms and financial consulting firms) attempted to elaborate both theoretical and empirical evaluation methods specifically designed to esteem the financial value of minority interests in companies listed on regulated markets (Pratt, Reilly, \& Schweihs, 2007; Nath, 1990). Starting from the assumption that such criteria are not specifically elaborated to evaluate the discount for reduced powers in sale/purchase transactions of minority interests in not listed companies, as they are "variations" to the aforesaid models to evaluate the control/majority premiums for holdings in companies listed on regulated markets (Ferraro, 2016; Booth 2001), in any case they have several common points, therefore may be taken partially as reference in this analysis.

Even more limited in number the studies are with respect to the analysis of the economic rationale behind minority discounts for reduced powers (Cheng \& Mak, 2015; Imen Ben \& Saoussen, 2013; Luo, Wan \& Cai, 2012), which are in most of the cases mere "adaptations" of theories developed in relation to majority premiums (Scheibel \& Klein, 2013).

Some researchers and practitioners have also focused on the valuation of minority discount for lack of marketability in the sale/purchase transactions of minority interests which cannot be easily sold to third parties within a reasonable period of time and for a fair value due to their absolute irrelevance from qualitative and quantity stand-point (Buchner, 2016; Chipalkatti \& Luft, 2013; Finnerty, 2013; Lazar \& Prisman, 2012). Notwithstanding such issue falls outside the scope of this article and it is a discount applied to minority interests in companies listed on official markets, similarly to the previous circumstance, also this one has some common points therefore it may be taken partially as reference in this analysis.

\section{Minority Discounts for Lack of Control}

If the interest bought/sold does not enable the purchaser to get full powers of control over the company, its market value is measured by deducting a pre-determinate discount rate from the relevant base value (that is measured by calculating the pro-rated value of the company's overall economic capital - W).

Specifically devaluation of minority interests with regard to the relevant base value of the interests exchanged is given by the following formula (Covrig, McConaughy and Travers, 2015; Ouimet, 2013; Zingales, 1995):

$$
W_{X}^{\prime}=S C_{X} W_{X}
$$

Where:

$W^{\prime} x$ is the discounted value of the exchanged minority holding;

$W x$ is the base-value of the minority holding (which is equal to the pro-rated value of the overall economic capital - $W$ );

$S C x$ is the discount percentage for lack of control.

The "magnitude" of the discount rate $(S C x)$ normally grows in a more than proportional means when the size of the exchanged interests grows (so called "leverage effect"), because in such way are higher the costs associated with the failure to achieve a full power of control over the company.

The economic rationale under such kind of minority discount has to be identified in the impossibility for the purchaser to gain the company's owner privileges (so called "prerogatives of control"), and specifically the power to distribute the company's resources at his lone judgement. Accordingly, the reasons for the purchasing of minority interests in the equity capital of an unquoted company must be sought entirely in the possibility of obtaining adequate financial revenues (specifically, dividends and capital gains), in such way the purchaser, having the role of a pure financial investor more than an entrepreneur bearing the enterprise risk (Liao, 2014; Massari, Monge \& Zanetti, 2006).

Control prerogatives/attributes may include:

a) Psychological, non-pecuniary benefits (so-called "reputational values") pertaining to the controlling position occupied (Masulis, Pham \& Zein, 2011);

b) Pecuniary "private" benefits, attributed to the controlling stakeholder exclusively and associated with the power to manage the company's assets and direct the cash flows outside the firm (Thraia, 2015; Albuquerque \& Schroth, 2010; Carvalhal Da Silva \& Subrahmanyam, 2007), fully or in part, towards entities controlled by the same controlling owner (so-called "external sinergies");

c) Pecuniary "private" benefits that the controlling stakeholder extracts from the firm to his own exclusive advantage (Lauterbach \& Barak, 2012; Nicodano \& Sembenelli, 2004; Doidge, 2004), which has its counterpart 
in the equivalent loss to minority stakeholders. This might result in an opportunistic accumulation of wealth and even in a looting of the firm's resources (so-called "tunnelling").

Type (a) benefits rarely generate the risk of compromising the interests of minority owners, and therefore do not contribute to define the class of minority discounts we are investigating (Dyck \& Zingales, 2004). Conversely, private advantages of type (b) - when the subsidiary firm is integrated into a superior business entity controlled by the same shareholder - and type (c) - when firm assets are used by the controlling owner for personal purposes - are intrinsically subject to that risk.

As for type (c) benefits in particular, when the controlling owner extracts pecuniary, private benefits by expropriating the firm's resources at the expense of minority stakeholders, it is evident that the profits of investments in risk capital obtainable from the firm's resources is inferior to the benefits obtainable in the absence of such expropriation. In theory, there are two different types of tunnelling:

1) Various types of misappropriation of firm's assets (so-called "self-dealing") that take place when:

- Assets are sold at unfairly favourable prices to entities somehow connected to the controlling owner (Johnson, La Porta, Lopez De Silanes \& Shleifer, 2000);

- Controlling stakeholders that occupy managerial positions inside the company are paid compensations which exceed market prices (Blanco, Haller, Lopez \& Walker, 2016; Poulsen, 2011);

- Money is lent under favourable terms to entities connected, directly or indirectly, to the controlling stakeholder (Baek, Kang \& Lee, 2006; Zingales, 1995);

- The controlling owner uses assets and/or firm services ("amenities" such as planes, cars, houses, chauffeurs, etc.) without adequately paying for them (Luo, Wan \& Cai, 2012);

2) One-off forms of assets transfer to the controlling stakeholder made without physically transferring the firm's resources, as when insider trading is carried out thanks to one's managerial role, or when assets and/or services are transferred to the firm capital at higher values than the market ones, or when stocks are issued at diluted prices etc. In other words, dividends due to minority stakeholders are reduced as a whole but the firm's assets are not reduced accordingly (so-called dilution).

Minority discounts for limited/reduced powers are normally calculated whenever minority interests in public held companies (i.e. those companies with a great number of stockholders) are estimated for trading purposes, as well as in closely held companies (i.e. those companies with a very few number of stakeholders, as in the case of SMEs) and family companies, or companies with particular administrative constraints (such as companies subdued to bankruptcy procedures or whose Articles of Association include "golden share" clauses). Specifically, a minority discount has to be calculated in the under-mentioned trading operations:

- Minority interest is purchased by someone (natural person or another company) who does not have further concerns in the company, or who is not able to turn into majority stakeholder still after that purchasing (Englebrecht, Anderson \& Martinson, 2006);

- Minority interest is purchased by someone who formerly holds a full controlling power on the firm (directly or indirectly).

On the contrary, this kind of minority discount should not be estimated if the traded interests, even though in absolute terms they constitute a minority in relation to the overall equity capital, anyhow grant the purchaser to influence the company's business operations (although not in a leading way as, if it were so, a control premium should be estimated) as of:

- The large number of stakeholders;

- The existence of factors that could make more difficult the achievement of requested quorums in the formal social meetings (e.g. the case of stakeholder's arrangements);

- The existence of adequate arrangements in the company's Articles of Association with regard to the corporate governance regime, as well as laws and/or regulations effectively in force in the Country in which the company is located that preserve minority holders versus the risk of abuse of dominant position potentially practicable by the majority owner and give the latter the capability to influence the top management's operations (e.g. the capability to designate a number of representatives - obviously the minority - in the governing and controlling boards).

\section{The Measurement of Minority Discounts for Reduced Powers}


Different kinds of methods have been elaborated by international researchers and practitioners to measure the discounted market value (W') of minority interests for reduced powers:

A) Direct methods, that are focused on a "stand alone" calculation of the monetary value specifically assignable to the minority interest under examination (Pratt, Reilly, \& Schweihs, 2007; Odegaard, 2007);

B) Indirect methodologies (Greene, 2014; Damodaran, 2012), that estimate the value of minority interests by computing a discount rate to the corresponding fraction of the overall base value (W).

Among the "direct" methods sub A), it is possible to recognize:

A1) Direct Comparison Approach, focused on the official market value of other minority interests concerning the same company or, in the absence of such data, analogous companies (in terms of size, core business, etc.) listed on official marketplaces;

A2) Bottom Up Method, based on the discounting back to an actual worth of dividends and capital gains foreseen in the near future from the minority interest under evaluation. Nevertheless ascertained that the actual esteeming of future realizable monetary value of unquoted company interests is quite tricky, it is preferable to capitalize the forecasted dividends for a limitless period of time (Zingales, 1995).

Methodology sub A1) is an empirical criterion at all, and it was specifically developed to measure the value of minority interests in public held companies listed on official markets. The economic rationale behind this method lies in the evidence that the stock price of any interest, when calculated over a period of significant duration in order to overcome possible information asymmetries and speculative trends, embodies a minority discount in itself given that only little blocks of shares (so-called free float), and certainly not majority holdings, are traded on official markets. Although such criterion is clearly not suitable for assessing the value of minority interests in non-listed businesses, it may occur that some practitioners still apply it by the fact of being based on effortlessly achievable data (Booth, 2001; Lazar and Prisman, 2012).

As for the Bottom Up criterion sub A2), the higher or lower measurable difference among the considered pro-quota value of the total economic capital (W) - the latter determined adopting valuation methods based on the actualization of cash flows or incomes expected in the future - and the economic worth of non-listed minority interests counts on the higher or lower rate to which profits are held and not paid out to stakeholders.

Accordingly the methodology at stake is focused on the hypothesis that controlling owners have different concerns and intentions from non-majority stakeholders. On one hand, the management's duty (and the controlling owner's will) is to increase the company's overall value (in both economic and financial terms) and so it should retain whole or partially the profits gained each year rather than pay it out in dividends in order to improve the firm's worth. On the other hand, minority stakeholders are not interested in governing the firm (because the interest is so small that it is useless for the purpose of obtaining the control of the company) but would like to monetize their investment by regularly gathering dividends and realizing good capital gain when trading their holdings. Accordingly, minority interests should have a reduced value compared to the corresponding portion of the overall economic capital because dividends paid out to minority stakeholders would be lower than the dividends that could be theoretically paid if the management distributed a larger portion of the profits achieved annually by the firm (on the base of controlling stakeholder's will) rather than retain them.

Therefore the magnitude W' does not designate the discounted value of minority interest exclusively, since any holding (so even a majority holding) when estimated with the criterion above would be smaller than the corresponding pro-rata value of the company's overall economic capital calculated with the income or financial method (Zingales, 1995). In the hypothesis that the allotment of dividends is proportionate to the size of the interests owned by each stakeholder, the adoption of the Bottom Up method involves that minority holdings are given a value that is proportionally equal to any other capital quota (included majority interests) and, as formerly remarked, to the overall value of the economic capital (with consequent "projection" on the latter of the minority discount). And either the methodology at stake is judged appropriate to measure the reduced value of minority interests or it's employing to estimate the company's overall economic capital (W) is accurate, but it is either one or the other.

Contrarily "indirect" methods sub B), also called Discount Approaches or Top Down Methods, measure the current value of minority interests by applying a discount rate to the corresponding fraction of the firm's overall "base" value. The magnitude of the discount rate can be calculated as indicated below (Shishido, 1993):

B1) On the basis of the minority discount rates effectively applied in past negotiations of minority interests concerning the same business or, in the shortage of such information, comparable businesses (in terms of size, core business, etc.) listed or non-listed on official marketplaces (Horizontal Method); 
B2) In inverse correlation of the magnitude of Control Premiums (CP) rates applied in past purchase/sale negotiations of majority interests concerning analogous businesses, listed or non-listed on official marketplaces (Mercer Capital Method), adopting the following formula:

$$
\text { Minority Discount }(S C x)=\left(1-\frac{1}{1+C P}\right) \%
$$

The approach sub B2) is of simple and brief utilization, given that it is conceivable to deduce control premium percentages (and then minority discount rates making use of the aforementioned equation) from a large number of financial databases (Jordan \& Worth, 2009). In the Anglo-Saxon countries, one of the databases mostly utilised by researchers and practitioners to measure control premium rates is the Control Premium Study issued annually by Mergerstat. This experienced institution measures control premium rates by calculating the percentage divergence between the controlling interest purchase/sale price that the counterparts arrange and the correlative official market price registered by five days previous the purchase/sale communiqué.

It is clear that both methodology sub B1) and methodology sub B2) are empirical criterion at all, and, as just pointed out, either share the same points of robustness and deficiency peculiar of this group of estimation criteria. Specifically, their adoption by international professional praxis is facilitated by the fact of being founded on effortlessly achievable data and that their utilization is quite punctual and intuitive.

Anyhow, it's a matter of fact that the methodologies at stake could transfer to current time the consequences of probable subjective conditions of negotiation that could have influenced the evaluation processes carried out previously and concerning majority and/or minority interests (Celli 2013). Additionally these methods could not distinguish among minority discounts for lack of control and discounts for lack of marketability, if and to the extent that the pro-rata value discounts executed formerly did not show any fair and reasoned divergence in that respect (as highlighted in the introduction, however, this kind of minority discount should apply only to irrelevant minority interests listed on official markets).

\section{Data Collection and Analysis}

\subsection{Research Design}

In the present paragraph we determine which of the mentioned methodologies for the estimation of the market value of minority interests in non-listed firms are normally utilised by professional praxis in a sample of European Countries.

The minority interests we examine in this research deal with the following tipologies of non-listed limited liability companies: German Aktiengesellschaft (A.G.), and Gesellschaft mit beschrankter Haftung (G.m.b.H.); English Public Limited Company (P.L.C.), and Limited Liability Company (L.l.c.) or Limited Company (L.t.d.); Italian Società per Azioni (S.p.A.), and Società a responsabilità limitata (S.r.l.); French Société Anonyme (S.A.), and Société à Responsabilité Limitée (S.à.r.l.); Spanish Sociedad Anonima (S.A.), and Sociedad Limitada or Societad de Responsabilidad Limitada (S.L.). No. 250 reports issued by an equal number of European financial experts (specifically, consulting firms, law firms and financial institution) concerning transactions of minority interests in non-listed businesses throughout the period 2000-2015 have been analysed. The financial reports under examination are alleged to their corresponding official public acts regarding purchase/sale agreements and filed with the Chamber of Commerce and/or the Courts and/or the Tax Revenue Agencies/IRS of the following towns: Berlin and Munich (Germany); London and Manchester (United Kingdom); Rome and Milan (Italy); Paris and Marseille (France); Madrid and Barcelona (Spain).

In order to have a sample survey, No. 50 financial reports have been selected for each of the mentioned European Countries, for this purpose considering only non-listed companies of medium and big size, classified in this way on the basis of the parameters specified by the European Commission with Recommendation No. EU/2003/361 of 6 May 2003 (specifically: annual work unit > 50; annual turnover > EUR 10 million; annual balance sheet total > EUR 10 million). Small enterprises have been excluded, as usually their shareholding structure does no encompass more shareholders (therefore it is the whole corporate capital being transferred and not portions thereof).

\subsection{Data Collection and Results}

The estimation methodologies utilised by the European professional practice to measure the minority discount for lack of control in the 250 reports of our sample are the following (each methodology is mentioned below in the same sequence as in paragraph 4 of this article):

A1) Direct Comparison Approach: No. 25

A2) Bottom Up Method: No. 65 
B1) Indirect Horizontal Method: No. 49

B2) Mercer Capital Method: No. 178

The number of estimation methodologies analysed (317) overcome the number of reports in the sample (250) because some experts have utilised two criteria together (a "principal" criterion and a "check" criterion) to estimate the market value of the same minority holding.

On the basis of the aforementioned data it seems clear that the most (56\%) used criterion by European praxis to measure the market value of minority interests in companies non-listed on official markets is the Mercer Capital Methodology, which belongs to the category of indirect criteria and, as previously mentioned, deducts the discount rate to be applied to the minority interests base value from the magnitude of control premium rates applied in past purchase/sale transactions of majority holdings in comparable companies (listed or non-listed on official markets). In our opinion this occurrence is easy to understand, as the aforementioned empirical methodology is of simple and immediate application since it is possible to extrapolate control premium values (and, indirectly, minority discount rates) from a large number of international financial databases.

Furthermore, it is interesting to highlight as the percentages of use of each of the above analysed methodologies for the valuation of minority interests in non-listed companies are basically uniform among the examined Countries, with the sole exception of United Kingdom, where the percentage of use of the Direct Horizontal Method (23\%) is significantly higher than the average value (8\%) observed in the remaining Countries.

The examination of the collected data was used to measure an average discount rate equal to $32 \%$, obviously in occurrences when such discounts for lack of control where defined using the Top Down methods (in fact such data can only be deducted by using methods sub 2) and 3) - i.e. Top Down criteria). The found range of minority discount rates was equal to $19 \%-47 \%$.

\section{Discussion and Conclusions}

The aim of this article was to give contribution to the issue of valuating the minority discount for reduced powers in purchase/sale transactions of minority interests non-listed on official markets. Firstly, it has been investigated the concept of minority discount for lack of powers and then analysed the economic reasons that motivate its valuation. In particular, we have highlighted that the economic rationale behind this type of minority discount lies in the impossibility for the minority purchaser to gain the prerogatives associated to the controlling position (so-called "private benefits of control"). Then we have examined the methods utilized to measure the market value of minority interests in the equity capital of companies unquoted on regulated markets (and so the minority discounts for reduced powers) elaborated by the main international doctrine. We examine the principal features of both direct and indirect valuation criteria specifically focusing on the second ones, which measure the value of minority interests by executing a discount percentage to the corresponding pro-rata value of the total economic capital (W). Finally, we have explored which valuation methodologies are more often utilised by the well-qualified professional practice in a number of European Countries.

In the light of the empirical results obtained, we may assume that in the European professional practice the market value of minority interests is calculated by applying a discount to the corresponding pro-rata value of the firm's economic capital ("found or base value"). The magnitude of such discount is usually estimated based on the percentage value of discount control premiums calculated in previous deals of majority interests in similar firms, quoted or unquoted on regulated markets (Mercer Capital Method).

Hence two magnitudes that international researchers and practitioners formerly consider as interchangeable are coupled also in material terms. Indeed, if control premiums estimate the extra-monetary worth connected to private benefits (both pecuniary and non-pecuniary) that pertain to the controlling position in a given business, then the absence of such "privileges", with regard to minority interests, involves a devaluation that, ceteris paribus, reflects the reduction in the base worth of the holding held.

Nevertheless, in our view, before even discussing the theoretical source of minority interest valuation criteria analysed above, the motivations themselves leading to the calculation of discounts for reduced powers should be debated in the first place, as there is no reasonable, logical correlation with control premiums.

As we know, the market value of an interest, in the lack of subjective conditions of negotiation, of illiquidity situations and of the benefits associated with controlling ownership, should in principle be equal to the underlying found value (pro-rata value of the economic capital), thus reflecting the allocated quota of future cash flows produced by the firm. If, conversely, the amount of interests held is such that the buyer acquires controlling powers over the firm, and consequently extracts the above-mentioned private benefits from his controlling position, then it is legitimate to increase the found relative value by a given percentage, in the form of 
a control premium. It is, however, illogical to apply a discount (ad adiuvandum, quantitatively derived from the above mentioned premium value) to the found value of a minority interest in the absence of such privileges, since its objective profitability is proportionally equal in value to that of the majority interest.

A minority discount for reduced powers would be justified only if the fruition of private benefits associated with the stakeholder's controlling power resulted in the impoverishment of the firm's assets, with consequent loss of profitability and of capital share value outside the controlling ownership. In the usual business management case, that is when the firm's policy is oriented towards creating value and ensuring the continuation of business over time, the presence of pecuniary and non-pecuniary benefits (as when controlling-holder uses the firm's assets for personal purposes) would explain the calculation of a premium at the time of transaction of controlling shares. Still, it would not justify, sic et simpliciter, a reduction of the found value of minority interests within the same firm, if there were no corresponding loss of the business' assets.

In other words, we believe that the valuation of discount rates is justified only if the activity of the controlling owner is geared towards asset misappropriation fraud (so-called tunnelling) to the detriment of minority shareholders. In this particular situation, the "physiological" extraction of private benefits normally associated with the controlling status goes beyond normal limits and the firm's economic value may be damaged. This occurs when the controlling holder carries out the following operations:

1) Firm assets spin-off to the benefit of subjects that are directly or indirectly related to the controlling holder not motivated by technical or economic reasons and in any case made at unfair market prices;

2) Income and/or cash flows are transferred to firms that are directly or indirectly controlled by the control-holder through "transfer pricing" processes;

3) The controlled company is used to operate against the law, and the responsibility of such illegal actions falls back on the firm itself.

Besides, the private benefits that controlling ownership extracts can be hindered (or completely impeded) by legal and extra-legal instruments, which may ensure adequate protection to non-controlling stakeholders (Holmen \& Knopf, 2004; Modigliani \& Perotti, 1997). Examples of legal instruments are:

- The legal environment itself, by which we designate the legal instruments which protect minority stakeholders and social creditors from the control-holder's tunneling policies but also the effective enforcement of such instruments by public and private supervising agencies;

- Suitable standards of accounting information (particularly with regard to annual financial statements and consolidated financial statements) to guarantee truthful and correct information about the economic and financial status of the concerned firm as well as of the management operations.

The word extra-legal factors refers to the existence of a moral code in all civilised societies according to which public opinion (minority shareholders, creditors, workers etc.) invigilates the activities and the work of control holders, as well as a very high level of competitiveness in the relevant market, considering that in such environment the possibility of the company to survive could be seriously jeopardised by the depletion deriving from the drawing for private benefits.

Consequently, we assume that in countries where protection (both legal and extra-legal) granted to non-controlling stakeholders is very low, the amount of private benefits that control-holders extract from their controlling position might be significantly high. Majority premiums will also be very high, compared to the found value of controlling holding, and minority discount for non-controlling interests will be higher correspondingly (Zhihong, Bin \& Zhifeng, 2013; Dyck \& Zingales, 2004). Conversely, in countries where complex and flexible regulations exist to prevent and punish such "looting policies" at the expense of minority stakeholders, valuating a discount based on the found value of minority interests would mean, in actual fact, to acknowledge that the control-holder is acting against the law (and against ethical values tout court). In such situations, there would be room for complaint to competent authorities and potential buyers might lose interest in the transaction (Delanga, 2015; Pinto, 2014).

Additionally, taking into account that the economic value of each component of the feature of control (the psychological factors as well as private benefits, in terms of cash but not only) can be separated from the overall value of exchange of the holding only in theory, whereas professional practice usually considers and, therefore, evaluates such components unitarily, the consequence is a remarkable difficulty for minority holders to prove in court the fraudulent purchase by the majority holders (Doidge, 2004; Nicodano \& Sembenelli, 2004). 
However, this very circumstance might represent a grounded motivation for valuating a discount for reduced powers. When such regulations are deliberately ignored or evaded by the controlling ownership (a circumstance that occurs with alarming frequency even in Countries with advanced legal systems), and when the competent authorities' action is slow and inefficient in preventing or sanctioning such unlawful behaviours (so called weak enforcement), the application of a more or less high discount to the minority interest base value would be justified to determine transaction price.

\section{References}

Albuquerque, R., \& Schroth, E. (2010). Quantifying private benefits of control from a structural model of block trades. Journal of Financial Economics, 96(1), 33-55. http://dx.doi.org/10.2139/ssrn.1448841

Bae, K.H., Kang, J.K., \& Kim, J.M. (2002). Tunneling or value added? Evidence from mergers by Korean business groups. The Journal of Finance, 57(3), 2695-2740. http://dx.doi.org/10.1111/1540-6261.00510

Baek, J.S., Kang, J.K., \& Lee, I. (2006). Business groups and tunneling: evidence from private securities offerings by Korean chaebols. The Journal of Finance, 61(5), 2415-2449. http://dx.doi.org/10.1111/1540-6261.00510

Barclay, M.J., \& Holderness, C. (1989). Private benefits from control of public corporations. Journal of Financial Economics, 23(3), 371-395.

Blanco, E., Haller, T., Lopez, M.C., \& Walker, J.M. (2016). The tension between private benefits and degradation externalities from appropriation in the commons. Journal of Economic Behavior \& Organization, 125(5), 136-147. http://dx.doi.org/10.1016/j.jebo.2016.02.0028

Bogatyrev, S.Y., \& Dobrynin, S.S. (2015). Takeover premiums and discounts for lack marketability in banking valuation: data from emerging markets. International Journal of Economic Perspectives, 9(2), 85-99.

Booth, R.A. (2001). Minority discounts and control premiums in appraisal proceedings. The Business Lawyer, 57(1), 127-161. http://dx.doi.org/10.2139/ssrn.285649

Buchner, A. (2016). How much can lack of marketability affect private equity fund values?. Review of Financial Economics, 28(1), 35-45. http://dx.doi.org/10.1016/j.rfe.2015.10.002

Carvalhal Da Silva, A., \& Subrahmanyam, A. (2007). Dual-class premium, corporate governance and the mandatory bid rule. Evidence from the Brazilian stock market. Journal of Corporate Finance, 13(1), 1-24. http://dx.doi.org/10.1016/j.jcorpfin.2006.12.003

Celli, M. (2014). The discount for lack of control in transactions of unquoted minority interests. Empirical evidence from Italy. European Journal of Business Research, 14(1), 47-52. http://dx.doi.org/10.18374/EJBR-14-1.4

Chari, A., Ouimet, P.P., \& Tesar, L.L. (2010). The value of control in emerging markets. The Review of Financial Studies, 23(4), 1741-1770. http://dx.doi.org/10.1093/rfs/hhp090

Cheng, L.T., \& Mak, S. (2015). Examining the discount-premium puzzle of private company valuation: the case of China. International Review of Accounting, Banking \& Finance, 7(3/4), 1-29.

Chipalkatti, N., \& Luft, C.F. (2013). Estimating the marketability discounts: a comparison. Journal of Applied Finance, 23(1), 23-39.

Cornell, B. (2013). Guideline public company valuation and control premiums. Journal of Business Valuation and Economic Loss Analysis, 8(1), 53-68. http://dx.doi.org/10.1515/jbvela-2013-0005

Covrig, V., McConaughy, D.L., \& Travers, M.K. (2015). Takeover premia and leverage: theory, empirical observations and recommendations. Journal of Business Valuation and Economic Loss Analysis, 10(6), 123-139. http://dx.doi.org/10.1515/jbvela-2015-00052

Covrig, V., McConaughy, D.L., \& Travers, M.K. (2016). Two methods to adjust observed control premia for valuation purposes. Business Valuation Review, 35(1), 19-34. http://dx.doi.org/10.5791/0882-2875-35.1.30

Damodaran, A. (2012). The value of control: implications for control premiums, minority discounts and voting share differentials. NYU Journal of Law \& Business, 8(2), 44-66. http://dx.doi.org/10.2139/ssrn.837405

Delanga, N. (2015). Minority protection in proceedings for the settlement of disputes between shareholders. Sociology Study, 5(6), 452-468. http://dx.doi.org/10.17265/2159 - 5526/2015.06.003

Doidge, C. (2004). U.S. cross-listings and the private benefits of control: evidence from dual-class firms. Journal of Financial Economics, 72(3), 519-553. http://dx.doi.org/10.1111/j.1540-6261.2008.01438.x 
Doidge, C., Karolyi, G.A., Lins, K.V., Miller, D.P., \& Stulz, R.M. (2009). Private benefits of control, Ownership and the cross-listing decision. The Journal of Finance, 64(1), 425-466. http://dx.doi.org/10.1111/j.1540-6261.2008.01438.x

Dyck, A., \& Zingales, L. (2004). Private benefits of control: an international comparison. The Journal of Finance, 59(2), 537-600. http://dx.doi.org/10.1111/j.1540-6261.2004.00642.x

Englebrecht, T. D., Anderson, M. M., \& Martinson, O. (2006). An empirical investigation of the minority interest and marketability discounts in valuation of closely held stock companies. Journal of Applied Business Research, 22(1), 9-23. http://dx.doi.org/10.19030/jabr.v22i1.1448

Ferraro, O. (2016). Business valuation: premiums and discounts in international professional practice. Eurasian Studies in Business and Economics, 4(3), 69-88. http://dx.doi.org/101007/978-3-319-39919-5-7

Finnerty, J. D. (2013). Using put option-based DLOM models to estimate discounts for lack of marketability. Business Valuation Review, 31-32(4), 165-170. http://dx.doi.org/10.5791/13-00001.1

Gopalan, R., \& Jayaraman, S. (2011). Private control benefits and earnings management: evidence from insider controlled firms. Journal of Accounting Research, 50(1), 117-157. http://dx.doi.org/10.1111/j.1475-679x.2011.00431.x

Greene, M. (2014). Minority interest discounts. The CPA Journal, 84(3), 38-50.

Hauser, S., \& Lauterbach, B. (2004). The value of voting rights to majority shareholders. Evidence from dual-class stock unifications. The Review of Financial Studies, 17(4), 1167-1184. http://dx.doi.org/10.1093/rfs/hhg061

Holmen, M., \& Knopf, J. D. (2004). Minority shareholder protections and the private benefits of control. The Journal of Financial and Quantitative Analysis, 38(1), 213-230. http://dx.doi.org/10.1017/S0022109000003938

Imen Ben, S., \& Saoussen, O. (2013). Empirical evidence of the relations between private benefits of control and asymmetric information. Journal of Business Studies Quarterly, 5(2), 141-159. http://dx.doi.org/10.4172/2151-6219.1000151

Johnson, S., La Porta, R., Lopez De Silanes, F., \& Schleifer, A. (2000). Tunneling. American Economic Review - Papers and Proceedings, 90, 22-27.

Jordan, D.J., \& Worth, D.H. (2009). A test of bear market mergerstat control premiums. Review of Quantitative Finance and Accounting, 33(1), 27-36. http://dx.doi.org/10.1007/s11156-008-0105-8

Lauterbach, B., \& Barak, R. (2012). Firm-specific factors affecting the private benefits of control in concentrated ownership economies. Advances in Financial Economics, 15(3), 11-23. http://dx.doi.org/10.1108/S1569-3732(2012)0000015005

Lazar, F., \& Prisman, E.Z. (2012). Evidence on lack of liquidity for small public firm. Journal of Business Valuation and Economic Loss Analysis, 7(1), 3-17. http://dx.doi.org/10.1515/1932-9156.1111

Liao, R.C. (2014). What drives corporate minority acquisitions around the world? The case for financial constraints. Journal of Corporate Finance, 26(3), 78-95. http://dx.doi.org/10.1016/j.jcorpfin.2014.02.007

Luo, J., Wan, D., \& Cai, D. (2012). The private benefits of control in Chinese listed firms. Do cash flow rights always reduce controlling shareholder's tunneling? Asia Pacific Journal of Management, 29(2), 499-518. http://dx.doi.org/10.1007/s10490-010-9211-y

Massari, M., Monge, V., \& Zanetti, L. (2006). Control premium in legally constrained markets for corporate $\begin{array}{lllll}\text { control. Journal of Management \& Governance, } & 10(1), & 79-96\end{array}$ http://dx.doi.org/110.10.1007/s10997-005-3560-9

Masulis, R.W., Pham, P.K., \& Zein, J. (2011). Family business groups around the world: financing advantages, control motivations and organizational choices. The Review of Financial Studies, 24(11), 3556-3600. http://dx.doi.org/10.1093/rfs/hhr052

Modigliani, F., \& Perotti, E. (1997). Protection of minority interest and the development of security markets. $\begin{array}{llll}\text { Managerial and Decision } & \text { Economics, }\end{array}$ http://dx.doi.org/528.10.1002/(SICI)1099-1468(199711/12)

Nath, E.W. (1990). Control premiums and minority interest discounts in private companies. Business Valuation Review, 9(2), 39-46. http://dx.doi.org/10.5791/0882-2875-9.2.39 
Nenova, T. (2003). The value of corporate votes and control benefits. A cross country analysis. Journal of Financial Economics, 68(4), 325-351. http://dx.doi.org/10.2139/ssrn.237809

Nicodano, G., \& Sembenelli, A. (2004). Private benefits, block transaction premiums and ownership structure. International Review of Financial Analysis, 13(2), 227-244. http://dx.doi.org/10.2139/ssrn.212248

Odegaard, B.D. (2007). Price differences between equity classes. Corporate control, foreign ownership or liquidity?. Journal of Banking and Finance, 31(12), 3621-3645. http://dx.doi.org/10.1016/j.jbankfin.2007.01.013

Ouimet, P.P. (2013). What motivates minority acquisitions? The trade-offs between a partial equity stake and complete integration. Review of Financial Studies, 26(4), 1021-1047. http://dx.doi.org/10.1093/rfs/hhs125

Pinto, A. (2014). Protection of Close Corporation Minority Shareholders in the United States. American Journal of Comparative Law, 62(5), 361-385.

Poulsen, T. (2011). Private benefits in corporate control transactions. International Review of Financial Analysis, 20(1), 52-58. http://dx.doi.org/10.1016/j.irfa.2010.10.002

Pratt, S.P. (2015). Discounts and Premiums, Wiley Edition, New York. http://dx.doi.org/10.1002/9781119197539.app6

Pratt, S. P., Reilly, R. F., \& Schweihs, R. P. (2007). Valuing a business: the analysis and appraisal of closely held companies, McGraw-Hill, NewYork. http://dx.doi.org/10.1023/A:1008618024253

Scheibel, M., \& Klein, C. (2013). What influences the discount applied to the valuation for non-controlling interests in private companies?. Journal of Business Valuation and Economic Loss Analysis, 8(1), 3-17. http://doi.org/10.1515/jbvela-2013-0008

Shishido, Z. (1993). The fair value of minority stock in closely held corporations. Fordham Law Review, 62(1), 65-110.

Suzuki, K. (2015). Estimating private benefits of control from stock price changes around the announcement of TOB. Public Policy Review, 11(3), 52-67. http://doi.org/10.2139/ssrn.891531

Thraia, M.F. (2015). Are controlling shareholders extracting private benefits from European public acquisitions? International Journal of Managerial Finance, 11(1), 80-96. http://dx.doi.org/10.1108/ijmf-07-2012-0081

Yee, K.K. (2005). Control premiums, minority discount and optimal judicial valuation. The Journal of Law and Economics, 48(2), 517-548. http://dx.doi.org/10.1086/429981

Zhihong, C., Bin, K., \& Zhifeng, Y. (2013). Minority Shareholders' Control Rights and the Quality of Corporate Decisions in Weak Investor Protection Countries. The Accounting Review, 88(4), 1211-1238. http://dx.doi.org/10.2308/accr-50424

Zingales, L. (1995). What determines the value of corporate votes? Quarterly Journal of Economics, 110(4), 1047-1073. http://dx.doi.org/10.2307/2946648

\section{Copyrights}

Copyright for this article is retained by the author(s), with first publication rights granted to the journal.

This is an open-access article distributed under the terms and conditions of the Creative Commons Attribution license (http://creativecommons.org/licenses/by/4.0/). 